\title{
Construction of News on the Shooting of Six FPI Soldiers at Tempo.co
}

\author{
Konstruksi Berita Kasus Penembakan Enam Laskar FPI \\ pada Tempo.co
}

\section{Vicky Pratama Putra}

\section{INSTITUTION}

Universitas Budi Luhur

Indonesia

\section{PHONE}

+6288210402635

\section{EMAIL}

vickypratamaaa@gmail.com

\section{DOI}

https://www.doi.org/

10.37010/prop.v2i1.526

\section{PAPER PAGE}

39-51

PROPAGANDA is a Journal of Communication Studies which is publish twice a year on January and July. PROPAGANDA is a scientific publication media in the form of conceptual paper and field research related to communication studies. It is hoped that PROPAGANDA can become a media for academics and researchers to publish their scientific work and become a reference source for the development of science and knowledge.

\begin{abstract}
Peristiwa penembakan yang terjadi antara anggota laskar Front Pembela Islam (FPI) dan Polisi menyebabkan enam anggota laskar meninggal dunia menjadi isu nasional yang menarik untuk diberitakan, sebab dari awal kasus ini terjadi terdapat dua versi yang di rilis oleh kedua belah pihak yang terlibat sehingga media akan mengonstruksikan realitasnya melalui apa yang mereka lihat. Konstruksi sendiri merupakan bagian dari framing atau bingkai media yang didasari oleh ideologi, pandangan politik, dan visi misi media itu sendiri dan dapat dilihat melalui penggunaan bahasa sebagai penonjolan makna. Hal tersebut menjadi dasar dilakukan penelitian dengan judul "Konstruksi Berita Kasus Penembakan Enam Laskar FPI pada Media Tempo.co (Analisis Framing Robert N. Entmann, periode 7 Desember 2020-27 Maret 2021" dengan rumusan masalah bagaimana Tempo.co melakukan framing berita kasus penembakan enam laskar FPI pada media Tempo.co. Salah satu metode penelitian yang mampu mendukung peneliti dalam menganalisis kasus ini adalah dengan metode penelitian kualitatif menggunakan metode analisis framing yang diperkenalkan oleh Robert N. Entman. Peneliti ingin melihat dan memahami bagaimana konstruksi realitas dan aspek-aspek yang lain yang dibangun oleh media untuk disampaikan kepada khalayak. Obyek dari penelitian ini adalah berita kasus penembakan enam laskar FPI yang dimuat oleh media online Tempo.co periode 7 Desember 2020-27 Maret 2021.

The shooting incident that occurred between members of the Islamic Defenders Front (FPI) and the police caused the death of six members of the Soldiers, which became an interesting national issue to be reported on, because from the beginning of this case there were two versions released by both parties involved so that the media would construct their reality through what they see. The construction itself is part of the framing or media frame based on ideology, political views, and the vision and mission of the media itself and can be seen through the use of language as a highlight of meaning. This became the basis for a research entitled "Construction of News on the Shooting of the Six Laskar FPI on Media Tempo.co (Analysis of Framing Robert N. Entmann, period 7 December 2020 - 27 March 2021" with the formulation of the problem of how Tempo.co framed news of shooting cases six FPI troops on Tempo.co media. One research method that is able to support researchers in analyzing this case is a qualitative research method using the framing analysis method introduced by Robert $N$. Entman. Researchers want to see and understand how the construction of reality and other aspects built by the media to be conveyed to the public. The object of this research is the news of the shooting of six FPI soldiers published by the online media Tempo.co for the period 7 December 202O - 27 March 2021.
\end{abstract}

\section{KEYWORD}

framing, berita, media online

framing, news, online media 


\section{PROPAGANDA}

\section{PENDAHULUAN}

Akhir-akhir ini jagat media online digemparkan oleh pemberitaan penembakan terhadap laskar FPI di KM50. Sejak pemimpin Front Pembela Islam (FPI), Habib Rizieq Shihab tiba di Indonesia dari Arab Saudi pada Selasa (10/11/2020) lalu, sejumlah peristiwa pun terjadi, seperti: mulai dari kerumunan massa yang menyambut kedatangan Habib Rizieq Shihab di bandara Soekarno-Hatta yang menyebabkan adanya kelumpuhan aktivitas selama lima jam; kedua, saat Habib Rizieq Shihab menghadiri peresmian masjid di Markas Syariah Pesantren Alam Agrokultural; ketiga, saat Habib Rizieq Shihab menggelar acara perayaan Maulid Nabi sekaligus pernikahan anaknya di kawasan Petamburan, Jakarta Pusat; keempat, Habib Rizieq Shihab menolak bertemu ketika sejumlah aparat mengajak beliau untuk tes Swab; kelima, polemik pulangnya Habib Rizieq Shihab dari RS Ummi Bogor; hingga Penembakan Laskar FPI di KM50.

Dilansir dari laman media Tempo.co, penembakan dilakukan pada Senin (7/12) dini hari saat rombongan Habib Rizieq Shihab bersama sejumlah pengawal sembilan unit kendaraan roda empat bergerak dari Perumahan The Nature Mutiara Sentul, ke sebuah tempat di Kabupaten Karawang, Jawa Barat. Mobil rombongan Habib Rizieq Shihab, dibuntuti sejak keluar gerbang kompleks perumahan, masuk ke gerbang tol Sentul Utara 2, hingga tol Cikampek dan keluar pintu tol Karawang Timur. Pergerakan iringan mobil masih normal, meskipun saksi FPI mengatakan adanya manuver mobil pengintai yang masuk ke rombongan iringan mobil Habib Rizieq Shihab.

Namun dari versi kepolisian mengaku hanya sesekali maju ke rombongan dari lajur kiri tol, untuk memastikan bahwa target pembuntutan (Habib Rizieq Shihab) berada dalam iringiringan. Sebanyak tujuh mobil rombongan Habib Rizieq Shihab melaju lebih dan meninggalkan dua mobil unit pengawalan lainnya. Kedua mobil FPI tersebut berhasil membuat jarak dan memiliki kesempatan untuk kabur dan menjauh. Namun, kedua mobil tersebut mengambil tindakan untuk menunggu mobil petugas kepolisian yang membuntuti. Tiga mobil yang membuntuti tersebut berplat K 9143 EL, B 1278 KJD, dan B 1739 PWQ. (Tempo.co, 2021)

Menurut temuan Komnas HAM telah terjadi aksi kejar mengejar, saling serempet dan seruduk, kemudian berujung saling serang dan kontak tembak antara mobil laskar khusus FPI dan mobil petugas. Insiden ini terjadi di sepanjang Jalan Internasional Karawang Barat dan diduga hingga kilometer 49 ruas Jalan Tol Jakarta-Cikampek. (Tempo.co, 2021) Akibat insiden ini dua orang anggota laskar FPI ditemukan dalam keadaan meninggal, sedangkan empat lainnya masih hidup dan dibawa dalam keadaan hidup oleh petugas kepolisian. Kemudian dari informasi petugas bahwa laskar yang dibawa petugas itu ditembak mati di dalam mobil saat dalam perjalanan dari Km. 50 menuju Polda Metro Jaya karena melawan dan mengancam keselamatan petugas.

Dalam peristiwa penembakan ini, setiap media online menyajikan berita sesuai dengan ideologinya masing-masing, seperti apa yang dimuat, bagaimana pengemasannya, apa aspek yang ditonjolkan dan dikeluarkan, semua ini mengarah pada sebuah konsep yang disebut framing. Peneliti memilih Tempo.co karena terkenal dengan gaya pemberitaannya yang terkesan tajam dan kritis.

Penelitian ini menarik untuk diteliti karena FPI merupakan sebuah organisasi yang cukup dikenal oleh masyarakat karena aksi-aksinya yang sering menimbulkan kontroversi yang berujung pada kekerasan. Selain aksinya yang kontroversial, tak jarang FPI juga terlibat konflik dengan pemerintah.

Berdasarkan kronologis kejadian di atas, peneliti tertarik membuat suatu penelitian ilmiah menggunakan objek penelitian berupa teks berita yang dimuat oleh media Tempo.co pada periode 7 Desember hingga 27 Maret 2021. Peneliti memilih periode ini karena rentetan 
peristiwa terjadi, mulai dari penembakan itu terjadi, lalu ada hasil investigasi dari Komnas HAM, kemudian temuan-temuan yang didapatkan oleh berbagai lembaga independen serta tuntutan dan desakan kepada pemerintah, hingga hal-hal janggal yang ada pada peristiwa penembakan tersebut.

Dalam kurun waktu tersebut terdapat 28 berita yang dimuat oleh Tempo.co yang terdiri dari berbagai headline dan artikel, setelah diseleksi berdasarkan pemilihan isu, peneliti dapat mengidentifikasi keseluruhan berita Tempo.co terkait pemberitaan kasus penembakan enam laskar FPI ini terbagi menjadi empat (4) berita moral, sepuluh (10) berita hukum, empat (4) berita politik, dan sepuluh (10) berita HAM. Dari 28 berita yang dimuat tersebut, peneliti tertarik untuk meneliti ke-10 berita yang mengarah ke ranah pelanggaran HAM.

Peneliti menggunakan objek penelitian teks berita yang dimuat oleh Tempo.co. Dalam pemberitaannya Tempo.co lebih banyak memuat narasumber dari Lembaga Independen seperti Komnas HAM, Komisi untuk Orang Hilang dan Korban Kekerasan (KontraS), Koalisi Aksi Menyelamatkan Indonesia (KAMI), Tim Pengawal Peristiwa Pembunuhan (TP3), Amnesty International Indonesia, Indonesian Police Watch (IPW), dan lain-lain yang menurut peneliti sangat berpengaruh dan berkapasitas. Hal inilah yang menjadi alasan peneliti menjadikan teks berita Tempo.co sebagai objek dalam penelitian ini.

Ada tiga pertimbangan sebuah peristiwa diangkat menjadi berita yaitu faktor ideologis, faktor politis, dan faktor bisnis. Tergantung pertimbangan mana yang dipilih oleh media untuk mengangkat berita tersebut, bergantung pada pengelola media bersangkutan. Pertimbangan ideologis karena faktor pemilik atau nilai-nilai yang dihayatinya. Pertimbangan politis menunjukkan bahwa pers tidak terlepas dari kehidupan politik. Apalagi pers disebut sebagai pilar keempat demokrasi (the fourth estate of democracy). Sedangkan kepentingan bisnis sangat berkaitan dengan pemasukan dari iklan (Suryawati dan Fitria, 2020).

Adapun model analisis yang digunakan peneliti dalam penelitian ini adalah analisis framing Robert N. Entmann dan teks berita yang dipilih adalah terkait pemberitaan penembakan enam laskar FPI yang dimuat pada 7 Desember 2020 hingga 27 Maret 2021. Alasan peneliti menggunakan model framing Entmann adalah karena dalam pemberitaannya, Tempo.co memiliki dua dimensi besar (Eriyanto, 2011), yaitu seleksi isu tentang HAM lebih banyak dari isu yang lain, kemudian terdapat juga penonjolan aspek berupa konotasi negatif maupun penonjolan aspek berupa kata-kata yang sering disebutkan di setiap pemberitaannya.

Selain dari dua dimensi besar seleksi isu dan penonjolan aspek, dalam konsepsi Entmann, framing pada dasarnya merujuk pada empat elemen yaitu pemberian definisi, penjelasan, evaluasi, dan rekomendasi dalam suatu wacana untuk menekankan kerangka berpikir tertentu terhadap peristiwa yang diwacanakan (Eriyanto, 2011). Dengan berbagai latar belakang yang sudah dijelaskan di atas, peneliti tertarik untuk meneliti Konstruksi Berita Kasus Penembakan Enam Laskar FPI pada Media Tempo.co.

\section{METODE}

Eriyanto (2011) dalam bukunya menjelaskan bahwa paradigma merupakan hal penting yang harus diperhatikan dalam penelitian, hal ini karena dapat membantu seorang peneliti dalam menghubungkan kerangka pikir yang dibuatnya dan metodologi penelitian yang digunakan. Dalam penelitian ini peneliti menggunakan paradigma konstruktivisme karena teks berita yang peneliti jadikan sebagai objek di atas tadi merupakan hasil konstruksi dan realitas yang bersifat subjektif, dengan memilih paradigma konstruktivisme, peneliti dapat melihat bagaimana suatu realitas di konstruksi oleh sebuah teks berita berdasarkan sudut pandang Tempo.co. (Moleong, 2018). 


\section{PROPAGANDA}

Pendekatan penelitian yang digunakan dalam penelitian ini adalah pendekatan kualitatif deskriptif, karena secara umum pendekatan ini digunakan untuk memperoleh hasil penelitian yang bersifat deskriptif dari kata-kata suatu objek penelitian (Moleong, 2018).

Pada penelitian ini, peneliti menggambarkan atau memaparkan suatu hasil penelitian dengan menggunakan teori-teori untuk menjelaskan peristiwa tersebut. Peneliti mengambil penelitian kualitatif, karena pada penelitian ini peneliti tidak menggunakan metode perhitungan untuk mendapatkan hasil penelitian, tetapi lebih kepada bagaimana mengungkap pembingkaian yang dibuat oleh Tempo.co dalam Pemberitaan Kasus Penembakan Enam Laskar FPI.

Metode yang digunakan dalam penelitian ini adalah analisis framing model Robert N. Entman. Entman melihat framing dalam dua dimensi besar, yaitu seleksi isu dan penekanan atau penonjolan aspek-aspek tertentu dari realitas atau isu. Selain dua dimensi besar, Entman juga merumuskan empat elemen framing yaitu define problem (pendefinisian masalah), diagnose causes (memperkirakan masalah atau sumber masalah), make moral judgement (membuat keputusan moral), dan treatment recommendation (menekankan penyelesaian) (Eriyanto, 2011).

Peneliti menggunakan teks berita Tempo.co terkait Berita Kasus Penembakan Enam Laskar FPI pada periode 7 Desember 2020-27 Maret 2021 yang didapat dari website resmi Tempo.co untuk dianalisis. Berikut adalah daftar berita yang akan dianalisis.

Tabel 1. Daftar Berita yang akan dianalisis pada Pemberitaan Tempo.co

\begin{tabular}{|c|c|c|}
\hline No. & Judul Berita & Keterangan \\
\hline 1 & $\begin{array}{l}\text { Penembakan Pengawal Rizieq Shihab, KontraS } \\
\text { Indikasikan ada Extrajudicial Killing }\end{array}$ & Selasa, 8 Desember 2020, pukul 09:52 \\
\hline 2 & $\begin{array}{l}\text { Penjelasan FPI Soal Kondisi } 6 \text { Jenazah Laskar: Ada } \\
\text { Lebih dari } 1 \text { Lubang Peluru }\end{array}$ & Rabu, 9 Desember 2020, pukul 19:07 \\
\hline 3 & $\begin{array}{l}\text { Presidium KAMI Nilai Penembakan } 6 \text { Laskar FPI } \\
\text { Brutal dan Kejam }\end{array}$ & Rabu, 9 Desember 2020, pukul 12:48 \\
\hline 4 & $\begin{array}{l}\text { Komnas HAM Akan Umumkan Bentrok KM. 50, FPI: } \\
\text { Semoga Allah Lindungi }\end{array}$ & Selasa, 5 Januari 2021, pukul 12:10 \\
\hline 5 & $\begin{array}{l}\text { Investigasi Komnas HAM: } 2 \text { Laskar FPI Sudah } \\
\text { Meninggal di Rest Area }\end{array}$ & Jumat, 8 Januari 2021, pukul 17:20 \\
\hline 6 & $\begin{array}{l}\text { Amnesty International Nilai } 6 \text { Anggota FPI adalah } \\
\text { Korban Pembunuhan Polisi }\end{array}$ & Sabtu, 9 Januari 2021, pukul 07:40 \\
\hline 7 & $\begin{array}{l}\text { TP3 Ajukan } 7 \text { Tuntutan kepada Pemerintah Soal } \\
\text { Penembakan } 6 \text { Laskar FPI }\end{array}$ & Senin, 1 Februari 2021, pukul 18:14 \\
\hline 8 & $\begin{array}{l}\text { Penembakan } 6 \text { Laskar FPI, Amien Rais Yakini Jokowi } \\
\text { Tak Berkenan Tuntaskan Kasus }\end{array}$ & Sabtu, 6 Maret 2021, pukul 13:45 \\
\hline 9 & $\begin{array}{l}\text { TP3: Penembakan Laskar FPI Jangan Berakhir Seperti } \\
\text { Kasus Novel Baswedan }\end{array}$ & Jumat, 12 Maret 2021, pukul 13:33 \\
\hline 10 & $\begin{array}{l}\text { Pengusutan Kasus Penembakan Laskar FPI, IPW: Polri } \\
\text { Jangan Grogi }\end{array}$ & Rabu, 24 Maret 2021, pukul 19:18 \\
\hline
\end{tabular}

\section{HASIL DAN PEMBAHASAN}

\section{Hasil}

Dua Dimensi Besar Berita Kasus Penembakan Enam Laskar FPI pada Media Tempo.co 1. Seleksi Isu

Aspek ini berkaitan dengan pemilihan kata. Dari realitas yang kompleks dan beragam, aspek mana yang akan diseleksi untuk ditampilkan? Dari proses ini di dalamnya selalu mengandung bagian berita yang tidak dimasukkan (included), tetapi ada juga berita yang 
dikeluarkan (excluded). Tidak semua aspek atau bagian dari isu ditampilkan, wartawan memilih aspek tertentu dari suatu isu. (Eriyanto, 2011)

Pada pemberitaan penembakan laskar FPI yang dimuat oleh media online Tempo.co lebih sering memunculkan isu pelanggaran HAM. Pada kesepuluh objek berita yang diteliti para narasumber dari berbagai lembaga membahas permasalahan tindakan sewenang-wenang yang dilakukan kepolisian terhadap enam laskar FPI, seperti kutipan berikut:

"Dari temuan penyelidikan Komnas HAM, kami menyimpulkan bahwa enam anggota FPI yang tewas adalah korban pembunuhan di luar proses hukum oleh aparat keamanan"

(Paragraf 2 pada artikel berita 17 dengan judul "Amnesty International Nilai 6 Anggota FPI adalah Korban Pembunuhan Polisi")

"Karena saat ini masih jauh dari harapan. Kami mencermati bahwa pembunuhan itu merupakan pembunuhan secara langsung terhadap penduduk sipil yang di dahului oleh penyiksaan dan dilakukan oleh sistematik. Kejahatan ini memenuhi kriteria sebagai kejahatan terhadap manusia sehingga merupakan pelanggaran HAM berat."

(Paragraf 2 pada artikel berita 18 dengan judul "TP3 Ajukan 7 Tuntutan kepada Pemerintah Soal Penembakan 6 Laskar FPI)

"Komisi untuk Orang Hilang dan Korban Tindak Kekerasan (KontraS) mengecam keras tindakan Anggota Kepolisian Republik Indonesia yang mengakibatkan kematian terhadap enam anggota Front Pembela Islam (FPI)"

(Paragraf 1 pada artikel berita 3 dengan judul "Penembakan Pengawal Rizieq Shihab, KontraS Indikasikan Ada Extrajudicial Killing")

Dalam penelitian ini peneliti menemukan fakta berita yang dimasukkan (included) dan dikeluarkan (excluded) oleh Tempo.co. Fakta yang dimasukkan (included) adalah pada berita ke-4 Tempo.co memuat Pimpinan Pusat Muhammadiyah sebagai narasumber yang mempertanyakan SOP Penembakan oleh Polisi di Kasus 6 Laskar FPI. Lalu fakta yang dikeluarkan (exluded) oleh Tempo.co yang sudah peneliti amati adalah, media online lain memuat berita yang menyebutkan bahwa penembakan terhadap anggota FPI sudah sesuai SOP. Adapun fakta yang di masukan (included) oleh Tempo.co adalah sebagai berikut:

"Muhammadiyah menyayangkan seolah polisi tak berupaya untuk melakukan olah TKP dan pengamanan di sekitar tempat kejadian. Apabila penembakan itu dilakukan karena polisi diserang saat melakukan penyelidikan, seharusnya penyidik melaporkan kejadian tersebut dan melakukan pengamanan tempat kejadian"

(Paragraf 3 pada artikel berita 4 dengan judul "Muhammadiyah Pertanyakan SOP Penembakan oleh Polisi di Kasus 6 Laskar FPI)

Selain itu peneliti juga menemukan fakta lain seperti berita yang dimasukkan (included) Tempo.co lebih menyoroti kinerja Indonesian Police Watch (IPW) dan Komnas HAM terkait bagaimana kedua lembaga tersebut melakukan penelusuran atau penyelidikan kasus penembakan ini. Sedangkan fakta yang dikeluarkan (excluded) oleh Tempo.co berbeda dengan media lain adalah, media lain lebih memuat pemberitaan terkait respons cepat Kapolri, Bareskrim, Divisi Propam, dan Divisi Hukum Polri. Dalam hal ini peneliti melihat bahwa Tempo.co ingin mengangkat kinerja IPW dan Komnas HAM terkait bagaimana IPW dan Komnas HAM melihat dan memutuskan kasus ini sehingga Tempo.co tidak secara langsung menetapkan kinerja kepolisian dalam mengusut kasus ini. Kemudian fakta ini dapat dibuktikan pada kutipan sebagai berikut:

"Bagi IPW sikap lambat itu tak lain akibat penyidik Polri grogi dalam mengusutnya. Padahal penyidik tak perlu grogi asalkan mereka mengikuti apa yang sudah menjadi arahan Komnas HAM, apalagi Komnas HAM sudah menegaskan bahwa dalam kasus ini terjadi pelanggaran HAM dan ini yang perlu dituntaskan pada titik mana pelanggaran HAM itu terjadi”

(Paragraf 2 dan 5 pada artikel berita dengan judul "Pengusutan Kasus Penembakan Laskar FPI, IPW: Polri Jangan Grogi”)

Kemudian peneliti juga menemukan fakta lain seperti berita yang di masukan (included) Tempo.co lebih menyoroti terkait tuntutan dan desakan kepada pemerintah oleh berbagai lembaga untuk membentuk tim independen pencari fakta memiliki porsi lebih banyak. Sedangkan fakta yang dikeluarkan (excluded) oleh Tempo.co berbeda dengan media lain adalah, media lain lebih menyoroti tentang tidak perlu membentuk tim pencari fakta dan 


\section{PROPAGANDA}

meminta masyarakat untuk memercayakan Komnas HAM dan kepolisian mengusut kasus ini. Adapun fakta yang dimasukkan (included) oleh Tempo.co adalah sebagai berikut:

"KAMI mendesak Presiden Jokowi membentuk Tim Independen Pencari Fakta untuk mengusut peristiwa tersebut secara obyektif, imparsial, dan transparan agar menyingkap pelaku dan pemberi perintah"

(Paragraf 2 pada artikel berita dengan judul "Presidium KAMI Nilai Penembakan 6 Laskar FPI Brutal dan Kejam)

\section{Penonjolan Aspek}

Aspek ini berkaitan dengan penulisan fakta. Ketika aspek tertentu dari isu tertentu dari suatu peristiwa atau isu tersebut telah dipilih, bagaimana aspek tersebut ditulis? Hal ini sangat berkaitan dengan pemakaian kata, kalimat, gambar, dan citra tertentu untuk dapat ditampilkan kepada khalayak (Eriyanto, 2011).

Peneliti menemukan penonjolan aspek berupa makna konotasi negatif terkait ketidakseriusan pemerintah untuk menuntaskan kasus pembunuhan yang menurut banyak pihak, peristiwa ini memenuhi syarat sebagai pelanggaran HAM berat. Penonjolan aspek berupa konotasi negatif yang ditemukan peneliti terdapat pada kalimat "Jokowi Tak Berkenan Tuntaskan Kasus" yang ada pada judul berita ke-8.

Selain itu peneliti juga menemukan penonjolan aspek berupa kata "Habib". Dalam pemberitaannya pada periode ini, Tempo.co hanya menyebutkan nama Rizieq Shihab saja tanpa gelar Habib, ini menjadi menarik karena tidak ada satu pun berita yang dimuat menyebutkan kata Habib, sedangkan media lain menyebutkan nama Rizieq Shihab beserta gelar Habib di depannya. Berdasarkan hal ini, peneliti melihat bahwa Tempo.co dalam pemberitaannya tidak ingin membawa gelar yang dimiliki dan murni melihat sebuah peristiwa tersebut berdasarkan kesalahan ataupun perbuatan yang dilakukan sejauh ini oleh Rizieq Shihab itu sendiri secara personal.

Selain kata Habib, peneliti juga menemukan penonjolan aspek berupa kata "Laskar". Dalam berita terkait penembakan laskar FPI, Tempo.co lebih banyak menyebutkan kata Laskar FPI dibandingkan Anggota FPI. Terbukti dalam pemberitaannya, Tempo.co menyebutkan kata "Laskar" sebanyak tiga puluh empat (34) kali. Hal ini menarik untuk dibahas karena dari pemilihan kata yang dipilih seolah menginformasikan kepada khalayak bahwa, keenam anggota FPI yang ditembak tersebut adalah bukan sekedar anggota biasa, melainkan anggota yang memiliki kemampuan atau pelatihan khusus, seperti sesuai dengan penjelasan KBBI yang mendefinisikan kata Laskar sebagai tentara atau kelompok serdadu maupun pasukan.

Selain itu peneliti juga menemukan penonjolan aspek berupa kata yang sering muncul dalam teks berita terkait pemberitaan penembakan laskar FPI di Km. 50. Berikut merupakan kata yang sering muncul dalam teks berita tersebut:

\begin{tabular}{cll} 
Tabel 2. Penonjolan Aspek Berupa Kata yang Sering Muncul dalam Pemberitaan Tempo.co \\
\hline No. & Kata atau Kalimat & Frekuensi \\
\hline 1 & Penembakan & 10 \\
2 & Pembunuhan & 5 \\
3 & Tewas & 7 \\
4 & Kejahatan & 2 \\
5 & Tembakan & 4 \\
6 & Pelanggaran HAM & 21 \\
7 & Komnas HAM & 25 \\
8 & Membentuk & 5 \\
9 & Mendesak & 8 \\
10 & Menuntut & 5 \\
11 & Investigasi & 12 \\
12 & Anggota FPI & 4 \\
13. & Laskar FPI & 34 \\
\hline
\end{tabular}




\begin{tabular}{ll}
\hline$\frac{14}{\text { Sumber: } \text { Teks Berita Tempo.co periode } 7 \text { Desember 2020-27 Maret 2021 }}$ & 8
\end{tabular}

Framing Robert N. Entman dalam Empat Elemen pada Pemberitaan Kasus Penembakan Enam Laskar FPI pada Media Tempo.co

1. Define Problem

Define problem atau pendefinisian masalah merupakan sebuah cara bagaimana peristiwa/isu itu dilihat atau sebagai masalah apa. Dalam pendefinisian masalah yang ditemukan, Tempo.co melihat sebuah peristiwa tersebut sebagai pelanggaran Hak Asasi Manusia yang dapat dilihat berdasarkan pernyataan narasumber yang dimuat dalam pemberitaan Tempo.co, seperti dalam kutipan berikut:

"Penelusuran Komnas HAM menemukan mereka masih hidup ketika tiba di rest area KM. 50, kemudian mereka meninggal ketika dibawa aparat. Sehingga kalau yang empat orang dalam penguasaan petugas resmi negara, maka itu adalah pelanggaran HAM."

(Berita 5: Investigasi Komnas HAM: 2 Laskar FPI Sudah Meninggal di Rest Area: Jum'at, 08/01/2021. Paragraf 5)

"Kami mencermati bahwa pembunuhan itu merupakan pembunuhan secara langsung terhadap penduduk sipil yang didahului oleh penyiksaan dan dilakukan oleh sistematik. Sehingga kejahatan ini memenuhi kriteria sebagai pelanggaran HAM berat."

(Berita 7: TP3 Ajukan 7 Tuntutan kepada Pemerintah Soal Penembakan 6 Laskar FPI: Senin, 01/02/2021. Paragraf 2)

\section{Diagnose Causes}

Diagnose causes memiliki arti sebagai perkiraan masalah atau sumber masalah bahwa peristiwa tersebut disebabkan oleh apa? Kemudian siapa aktor yang dianggap sebagai penyebab masalah. Dalam pemberitaannya, Tempo.co melihat sebuah peristiwa ini disebabkan oleh tewasnya enam laskar FPI di tangan polisi ketika para anggota FPI tersebut sedang melakukan pengawalan perjalanan Habib Rizieq menuju sebuah lokasi di Karawang. Seperti pada kutipan berita berikut ini:

"Para anggota Laskar FPI itu dikabarkan tengah mendampingi perjalanan Imam Besar Mereka, Rizieq Shihab di Jalan Tol Cikampek KM. 50"

(Berita 2: Penjelasan FPI Soal Kondisi 6 Jenazah Laskar: Ada Lebih dari 1 Lubang Peluru, Rabu, 09/12/2020. Paragraf 4)

"Dari temuan penyelidikan Komnas HAM, kami menyimpulkan bahwa enam anggota FPI yang tewas adalah korban pembunuhan di luar proses hukum oleh aparat keamanan"

(Berita 6: Amnesty International Nilai 6 Anggota FPI adalah Korban Pembunuhan Polisi: Jum'at, 08/01/2021. Paragraf 3)

\section{Make Moral Judgement}

Make moral judgement berarti nilai moral apa yang disajikan untuk menjelaskan masalah. Dalam penelitian ini, penilaian moral yang dilakukan oleh Tempo.co adalah untuk men-delegitimasi atau tidak membenarkan tindakan penembakan yang dilakukan terhadap enam laskar FPI tersebut. Meskipun diduga keenam laskar FPI ini memiliki kesalahan, terlepas dari itu keenam laskar ini tidak berhak mendapatkan tindakan seperti itu sebelum proses hukum diputuskan. Penyajian nilai moral yang diteliti pada berita ini dijelaskan pada kalimat berikut:

"Dalam konteks kematian enam orang yang sedang mendampingi Rizieq Shihab, anggota kepolisian sewenang-wenang dalam penggunaan senjata api karena tidak diiringi dengan membuka akses seterang-terangnya dengan memonopoli informasi penyebab peristiwa tersebut"

(Berita 1: Penembakan Pengawal Rizieq Shihab, KontraS Indikasikan ada Extrajudicial Killing: Selasa, 08/12/2021. Paragraf 5)

"Presidium KAMI mengatakan, tindakan tersebut hanya dilakukan orang-orang yang tidak pancasilais atau tidak berketuhanan yang maha esa, dan berkeperimanusiaan yang adil dan beradab."

(Berita 3: Presidium KAMI Nilai Penembakan 6 Laskar FPI Brutal dan Kejam: Rabu,

09/12/2021. Paragraf 5) 


\section{PROPAGANDA}

\section{Treatment Recommendation}

Untuk menyelesaikan masalah dalam berita yang diteliti, peneliti melihat bahwa Tempo dalam pemberitaannya terfokus pada tuntutan dan desakan dari lembaga-lembaga independen kepada pemerintah agar segera menuntaskan kasus penembakan ini.

"Ketujuh tuntutan itu adalah menuntut nama-nama pelaku pembunuhan yang dilaporkan Komnas HAM kepada Presiden Joko Widodo segera diumumkan; menuntut Jokowi sebagai kepala negara untuk ikut bertanggung jawab atas tindakan sewenang-wenang aparat negara dalam peristiwa tersebut"

(Berita 7: TP3 Ajukan 7 Tuntutan kepada Pemerintah Soal Penembakan 6 Laskar FPI: Jum'at, 01/02/2021. Paragraf 3)

"KAMI mendesak Presiden Jokowi membentuk Tim Independen Pencari Fakta untuk mengusut peristiwa tersebut secara obyektif, imparsial, dan transparan agar menyingkap pelaku dan pemberi perintah"

(Berita 3: Presidium KAMI Nilai Penembakan 6 Laskar FPI Brutal dan Kejam: Rabu, 09/12/2020. Paragraf 2)

"Maka itu, Usman mendesak hasil investigasi Komisi Nasional Hak Asasi Manusia (Komnas HAM) penting untuk segera ditindaklanjuti. Sebab, hal tersebut dapat memastikan proses akuntabilitas."

(Berita 6: Amnesty International Nilai 6 Anggota FPI adalah Korban Pembunuhan: Sabtu, 09/01/2021. Paragraf 6)

"Selain itu, TP3 meminta agar kasus penembakan laskar FPI disidangkan di Pengadilan HAM dan meminta Polri bekerja keras untuk mengeksplorasi indikator-indikator di lapangan sehingga ditemukan alat bukti yang mengarah ke pelanggaran HAM Berat"

(Berita 10: TP3: Penembakan Laskar PFI Jangan Berakhir Seperti Kasus Novel Baswedan: Jumat, 12/03/2021. Paragraf 6)

\section{Pembahasan}

\section{Frame Tempo.co: Isu HAM}

Dapat dilihat dari hasil penelitian yang peneliti lakukan terkait pemberitaan penembakan laskar FPI pada media online Tempo.co periode 7 Desember 2020 hingga 27 Maret 2021 menggunakan analisis framing Robert N. Entmann, peneliti melihat bagaimana Tempo.co lebih memilih isu pelanggaran HAM yang ditampilkan. Ada beberapa alasan mengapa Tempo.co menampilkan isu ini, yang pertama bisa dilihat dari pemilihan narasumber yang dimuat, seperti Amnesty International Indonesia yang menyimpulkan bahwa enam anggota FPI yang tewas adalah korban pembunuhan di luar proses hukum oleh aparat keamanan. Selain itu ada Marwan Batubara yang merupakan salah satu inisiator Tim Pengawal Peristiwa Pembunuhan (TP3) yang menyebutkan bahwa pembunuhan terhadap enam anggota laskar FPI itu merupakan pembunuhan secara langsung terhadap penduduk sipil yang didahului oleh penyiksaan dan dilakukan secara sistematik.

Kemudian isu pelanggaran HAM ini menjadi valid ketika Komnas HAM menemukan bahwa ada empat orang anggota yang masih hidup ketika tiba di Rest Area KM. 50, kemudian keempat orang anggota ini diminta keluar dari mobil dan tiarap dan di masukan ke dalam mobil petugas kepolisian, kemudian keempat anggota tersebut akhirnya meninggal ketika dibawa aparat. Berikut kutipan beritanya:

"Jadi agak berbeda, kalau yang empat orang dalam penguasaan petugas resmi negara, maka itu adalah pelanggaran HAM."

(Paragraf ke-5 dalam artikel berita dengan judul "Investigasi Komnas HAM: 2 Laskar FPI

Sudah Meninggal di Rest Area")

Berdasarkan hal tersebut, peneliti beranggapan bahwa Tempo.co ingin menunjukkan bahwa walaupun keenam anggota laskar FPI ini diduga melakukan pelanggaran hukum tetapi mereka tetap memiliki hak ditangkap dan dibawa ke persidangan untuk membuktikan apakah tuduhan tersebut benar. 
Kemudian Tempo.co juga menghadirkan Amien Rais dari TP3 yang beranggapan bahwa Presiden Jokowi tidak berkenan untuk menuntaskan kasus pembunuhan terhadap enam anggota FPI karena sikap yang ditunjukkannya. Kemudian ada Neta S. Pane selaku Presidium Indonesian Police Watch (IPW) yang menilai bahwa langkah kepolisian dalam mengusut kasus penembakan ini cenderung lambat dan grogi. Neta juga meminta kepada Polri agar lebih menunjukkan komitmen mereka, terlebih adanya sorotan tajam yang diarahkan kepada penyidik Polri yang dikhawatirkan tidak netral dalam menyidik kasus ini.

Dalam penelitian ini, peneliti menemukan fakta berita yang dimasukkan (include) dan fakta berita yang dikeluarkan (exclude) oleh Tempo, seperti fakta yang di masukan (include) oleh Tempo.co dapat dilihat pada berita ke-4 Tempo.co yang memuat Pimpinan Pusat Muhammadiyah sebagai narasumber yang mempertanyakan SOP Penembakan oleh Polisi di Kasus 6 Laskar FPI. Lalu fakta yang dikeluarkan (exclude) oleh Tempo.co yang berbeda dengan media lain adalah media online lain memuat berita yang menyebutkan bahwa penembakan terhadap anggota FPI sudah sesuai SOP. Berdasarkan penjelasan tersebut, dapat disimpulkan bahwa Tempo.co ingin menginformasikan kepada khalayak bahwa adanya pelanggaran yang dilakukan oleh kepolisian dalam peristiwa ini.

Fakta selanjutnya yang di masukan (incude) oleh Tempo.co adalah Tempo.co dalam pemberitaannya lebih menyoroti terhadap kinerja lembaga independen seperti Indonesian Police Watch (IPW) dan Komnas HAM dalam melakukan penelusuran kasus penembakan ini. Sedangkan fakta yang dikeluarkan (exclude) oleh Tempo.co yang berbeda dari media lain adalah, media lain lebih memuat pemberitaan terkait respons cepat Kapolri, Bareskrim, Divisi Propam, dan Divisi Hukum Polri untuk membentuk tim khusus untuk menindak lanjuti temuan Komnas HAM. Dalam hal ini, IPW menilai bahwa langkah kepolisian dalam mengusut kasus penembakan yang dilakukannya terkesan lambat bahkan seakan grogi dalam melakukan penyelidikannya. Hal ini menjadi menarik karena Tempo.co tidak menilai kinerja kepolisian secara langsung melainkan menggunakan pihak lain untuk disajikan kepada khalayak.

Kemudian peneliti juga menemukan fakta lain yang dimasukkan (include) bahwa dalam pemberitaannya Tempo.co lebih menyoroti terkait tuntutan dan desakan kepada pemerintah untuk membentuk tim independen pencari fakta demi sebuah penyelidikan yang obyektif dan transparan seperti yang diajukan oleh Tim Pengawal Peristiwa Penembakan (TP3). Sedangkan fakta yang dikeluarkan (exclude) oleh Tempo.co yang berbeda dari media lain adalah, media lain lebih menyoroti pemberitaan tentang tidak diperlukannya tim pencari fakta lain dan meminta masyarakat untuk mempercayakan investigasi kasus ini kepada pihak kepolisian dan Komnas HAM.

Pada penelitian ini, peneliti juga menemukan penonjolan aspek berupa konotasi negatif yang ditonjolkan pada pemberitaan Tempo.co. kalimat yang mengandung konotasi negatif terdapat pada judul berita "Muhammadiyah Pertanyakan SOP Penembakan oleh Polisi di Kasus 6 Laskar FPI". Pada judul berita tersebut, Tempo.co menegaskan bahwa perlu diadakan evaluasi terhadap pola penanganan penggunaan senjata api oleh pihak kepolisian karena diduga dalam peristiwa penembakan itu prinsip penanganan perkara telah diabaikan. Sehingga menurut Tempo.co anggota yang melakukan penyelidikan kasus kerumunan Rizieq dan atasannya perlu diperiksa.

Selain penonjolan aspek berupa konotasi negatif, peneliti juga menemukan penonjolan aspek berupa pengulangan kata yang sering muncul pada pemberitaan Tempo.co terkait penembakan laskar FPI di KM. 50. Kata yang sering muncul dalam pemberitaan Tempo.co yang pertama adalah kata "Anggota FPI" dan "Laskar FPI", pada penonjolan aspek dalam kedua kata ini peneliti beranggapan bahwa Tempo.co ingin menjelaskan maksud lain kepada khalayak bahwa tidak hanya sekedar kata Anggota atau Laskar, terbukti dalam pemberitaannya Tempo.co lebih memilih menggunakan kata Laskar dibandingkan Anggota. Dalam hal ini peneliti melihat bahwa enam anggota korban tewas tersebut bukan hanya sekadar anggota, 


\section{PROPAGANDA}

tetapi anggota yang memiliki kemampuan dan pelatihan khusus sesuai dengan penjelasan KBBI yaitu sebuah tentara atau kelompok serdadu ataupun pasukan.

Sama halnya dengan kata Laskar dan Anggota, pada penonjolan aspek berupa kata "Habib Rizieq Shihab" dan "Rizieq Shihab ini peneliti melihat bahwa Tempo.co tidak ingin membawa gelar yang dimiliki dan murni melihat sebuah peristiwa tersebut berdasarkan kesalahan ataupun perbuatan yang dilakukan sejauh ini oleh Eks Ketua Umum FPI itu sendiri secara personal. Hal ini dapat dibuktikan dalam setiap pemberitaan mengenai penembakan laskar FPI, tidak ada satu pun berita yang memuat kata Habib. Hal ini menjadi menarik ketika pada media lain menyebutkan nama Habib, tetapi Tempo.co tidak menyebutkan sama sekali.

Kata yang sering muncul berikutnya adalah "Pelanggaran HAM", meliputi kata extrajudicial killing/unlawfull killing, kata ini disebutkan sebanyak dua puluh satu (21) kali, peneliti beranggapan bahwa Tempo.co ingin menunjukkan bahwa pihak kepolisian telah melakukan pelanggaran HAM karena tidak mampu menghindari jatuhnya korban. Penonjolan aspek kata yang ditemukan berikutnya adalah "Korban", Tempo.co ingin menginformasikan kepada khalayak bahwa enam anggota laskar FPI adalah korban pembunuhan dan tindakan sewenang-wenang aparat keamanan.

Lalu kata selanjutnya adalah "Investigasi", Tempo.co ingin menunjukkan kepada khalayak bahwa Komnas HAM akan ikut menginvestigasi dan mencari kemungkinan adanya pelanggaran HAM. Kemudian kata lain yang sering muncul adalah "Penembakan", Tempo.co ingin menginformasikan kepada khalayak bahwa telah terjadinya penembakan terhadap enam anggota laskar FPI saat rombongan Habib Rizieq Shihab bersama sejumlah pengawal bergerak dari Sentul ke Karawang, Jawa Barat.

Selain menemukan seleksi isu dan penonjolan aspek, peneliti juga menemukan empat (4) elemen framing yang terdapat pada pemberitaan Tempo.co. Elemen pertama yang ditemukan peneliti adalah define problem, penjelasan pada elemen ini adalah pendefinisian masalah yang ditemukan pada pemberitaan yang mencakup ke dalam masalah pelanggaran HAM, seperti temuan Komnas HAM yang mengatakan bahwa ada empat orang anggota laskar yang masih hidup ketika tiba di Rest Area KM. 50, lalu keempat anggota laskar ini diminta keluar dari mobil dan tiarap, kemudian dimasukkan ke dalam mobil petugas kepolisian dan akhirnya keempat laskar ini meninggal ketika dibawa aparat. Sehingga berdasarkan temuan tersebut Komnas HAM dalam investigasinya menyatakan bahwa kejadian terebut termasuk sebagai pelanggaran HAM.

Lalu, penjelasan masalah yang sama juga terdapat pada konferensi pers secara daring oleh salah satu Inisiator Tim Pengawal Peristiwa Pembunuhan (TP3) yang menyebutkan bahwa pembunuhan itu merupakan pembunuhan secara langsung yang didahului oleh penyiksaan sehingga kejahatan ini memenuhi kriteria sebagai pelanggaran HAM Berat.

Peneliti juga menemukan diagnose causes yaitu perkiraan masalah atau sumber masalah pada pemberitaan penembakan laskar FPI yang di mana dalam pemberitaannya, Tempo.co melihat sumber masalah dalam peristiwa ini disebabkan oleh tewasnya enam laskar FPI ketika sedang melakukan pengawalan Imam Besar mereka ke salah satu tempat di Karawang. Atas hal itu Tempo.co menganggap pihak kepolisian sebagai aktor penyebab masalah dalam peristiwa ini.

Selain define problem dan diagnose causes, peneliti juga menemukan make moral judgement atau keputusan moral yang dibuat oleh Tempo.co terkait peristiwa penembakan enam laskar FPI. Keputusan moral yang ditampilkan Tempo.co adalah tidak membenarkan atau mendelegitimasi tindakan sewenang-wenang aparat keamanan terhadap enam laskar FPI, sekalipun keenam laskar FPI tersebut diduga melakukan kesalahan hingga proses hukum diputuskan oleh yang berwenang. 
Atas dasar itu Presidium Koalisi Aksi Menyelamatkan Indonesia (KAMI) mengatakan bahwa tindakan tersebut hanya dilakukan oleh orang-orang yang tidak berketuhanan dan berkeperimanusiaan.

Treatment recommendation atau penyelesaian masalah yang ditemukan peneliti dalam pemberitaan Tempo.co adalah, dalam pemberitaannya peneliti melihat bahwa Tempo.co lebih banyak memuat berita terkait tuntutan dan desakan dari berbagai lembaga independen kepada pemerintah agar segera menuntaskan kasus penembakan ini. Seperti tuntutan yang diajukan oleh TP3 yang menuntut nama-nama pelaku pembunuhan yang dilaporkan Komnas HAM kepada Presiden Jokowi untuk segera diumumkan dan juga menuntut Jokowi sebagai kepala negara untuk ikut bertanggungjawab atas tindakan aparat negara dalam peristiwa penembakan ini. Kemudian desakan juga muncul dari Koalisi Aksi Menyelamatkan Indonesia (KAMI) yang mendesak Presiden Jokowi membentuk tim independen pencari fakta demi pengusutan yang obyektif, imparsial, dan transparan agar dapat menyingkap pelaku dan ditemukan juga siapa yang memberi perintah penembakan tersebut. Selain itu, Usman dari Amnesty International Indonesia juga mendesak hasil investigasi Komnas HAM penting untuk segera ditindaklanjuti. Sebab, hal tersebut dapat memastikan proses akuntabilitas. Kemudian, TP3 juga meminta agar pihak kepolisian bekerja keras untuk mengeksplorasi indikator-indikator di lapangan hingga ditemukannya alat bukti yang mengarah ke pelanggaran HAM Berat.

\section{PENUTUP}

Berdasarkan hasil penelitian yang ditemukan oleh peneliti pada teks berita Tempo.co terkait penembakan enam laskar FPI periode 7 Desember 2020 - 27 Maret 2021 menggunakan teknik analisis framing Robert N. Entman, peneliti dapat menarik kesimpulan bahwa dalam pemberitaannya, Tempo.co lebih memfokuskan permasalahannya pada isu HAM dengan lebih banyak memuat narasumber dari lembaga independen dibandingkan instansi pemerintahan. Semua menunjukkan satu hal bahwa Tempo.co menempatkan Polisi sebagai pihak yang salah karena tindakan sewenang-wenangnya terhadap masyarakat sipil tanpa mengupayakan hal lain agar tidak ada jatuhnya korban. Padahal keenam laskar FPI tersebut memiliki hak untuk dibawa ke persidangan untuk membuktikan apakah tuduhan yang beredar tersebut benar.

Hal tersebut diperjelas dengan pemilihan kata dan penggunaan istilah yang secara tidak langsung menyiratkan keberpihakan Tempo.co pada FPI. Dalam pemberitaannya, Tempo.co beberapa kali menggunakan pilihan diksi seperti "penembakan", "tewas", "pelanggaran HAM", "korban", "menuntut dan mendesak", yang memberi kesan bahwa tindakan penembakan tersebut adalah sebuah tindakan melanggar hukum dan memenuhi kriteria sebagai pelanggaran HAM berat. Tempo.co juga menggunakan istilah seperti "laskar" dan "Rizieq Shihab" yang menurut peneliti pemilihan kata tersebut menunjukkan bahwa Tempo.co ingin menjelaskan maksud lain kepada khalayak bahwa anggota yang ditembak tersebut bukan sekadar anggota biasa, melainkan anggota yang memiliki kemampuan dan pelatihan khusus.

Sama halnya dengan "laskar dan anggota" pemilihan kata "Rizieq Shihab" tanpa gelar habib pun menjadi menarik untuk diteliti, karena jika pada media lain menyebutkan gelarnya, Tempo.co tidak satu pun menyebutkan gelar tersebut dalam semua pemberitaannya terkait berita kasus penembakan enam laskar FPI. Berdasarkan hal tersebut, peneliti beranggapan bahwa dalam kasus ini Tempo.co tidak ingin melihat histori buruk yang melekat pada tubuh eks Imam Besar FPI ini melainkan murni melihat peristiwa tersebut sebagai Rizieq Shihab secara personal sebagai masyarakat sipil.

Pada pendefinisian masalah, peneliti menyimpulkan bahwa peristiwa penembakan enam laskar FPI ini mencakup ke dalam isu HAM, karena dalam pemberitaannya Tempo.co lebih banyak memuat narasumber dari ranah HAM. kemudian dari narasumber tersebut sepakat 


\section{PROPAGANDA}

bahwa pembunuhan itu merupakan pembunuhan di luar proses hukum yang didahului oleh penyiksaan sehingga memenuhi kriteria sebagai pelanggaran HAM berat.

Peneliti menyimpulkan bahwa Tempo.co melihat sumber masalah dalam peristiwa ini disebabkan oleh tewasnya enam laskar FPI dan menetapkan pihak kepolisian sebagai aktor penyebab masalah. Kemudian keputusan moral yang ditampilkan Tempo.co yang peneliti simpulkan adalah Tempo.co tidak membenarkan atau mendelegitimasi tindakan sewenangwenang aparat keamanan terhadap enam laskar FPI, sekalipun keenam laskar FPI tersebut diduga melakukan kesalahan hingga proses hukum diputuskan.

Peneliti menyimpulkan bahwa Tempo.co menekankan penyelesaian masalah dengan memuat berbagai tuntutan dan desakan dari berbagai lembaga independen untuk segera menuntaskan kasus penembakan ini seperti desakan untuk membentuk tim pencari fakta hingga menuntut presiden Jokowi sebagai kepala negara untuk ikut bertanggung jawab atas tindakan aparat negara dalam peristiwa penembakan ini.

\section{DAFTAR PUSTAKA}

Afdjani, H. (2013). Ilmu Komunikasi Proses \& Strategi. Tangerang: Indigo Media Asep Syamsul, R. (2012). Jurnalistik Online: Panduan Mengelola Media Online. Bandung: Nuansa Cendikia

Basit, A. (2007). Relasi Antara Ideologi dengan Media Massa. Purwokerto: Jurusan Dakwah Stain Purwokerto.

Eriyanto. (2011). Analisis Framing-Konstruksi, Ideologi, dan Politik Media. Yogyakarta: LKiS.

Kriyantono. (2006). Riset Komunikasi. Jakarta: Kencana

Lexy, J. M. (2008). Metodologi Penelitian Kualitatif. Bandung: PT Remaja Rosdakarya

Romli, A. S. (2014). Jurnalistik Online: Panduan Mengelola Media Online. Bandung: Nuansa Cendikia.

Yulianita, M. (2021). "Bingkai Pemberitaan Kasus Penembakan 6 Laskar FPI". Program Sarjana Universitas Sriwijaya

Suryawati, I. (2011). Jurnalistik Suatu Pengantar Teori dan Praktik. Bogor: Ghalia Indah.

Fitria, U. \& Suryawati, I. (2020). Politainment News Framing of DPR RI Members Mulan Jameela on The Online Media. KOMUNIDA: Media Komunikasi dan Dakwah, 10(01) https://www.gurupendidikan.co.id/feature/ (diakses pada 24/05/21, 21:23) https://www.tempo.co/about (diakses terakhir pada 17 Januari 2022, pukul 19:39) https://korporat.antaranews.com/tentang/sejarah-singkat, (diakses pada 22 April 2021 pukul $10: 23)$

https://tirto.id/sejarah-majalah-tempo-bermula-dari-modal-ciputra-emug, (diakses pada 6 Oktober 2021, pukul 08:59) 